\title{
Penerapan Pendekatan VCT ( Value Clarification Teaching ) Untuk Meningkatkan Kedisiplinan dan Hasil Belajar IPS Pada Siswa Kelas V SDN Telaga Waru Kec. Praya, Kab. Lombok Tengah Tahun Pelajaran 2017/2018
}

\author{
H. AMINUDIN \\ Guru kelas SDN Telaga Waru Kec. Praya \\ Kabupaten Lombok Tengah
}

\begin{abstract}
Abstarak; pesatnya perkembangan ilmu pengetahuan dan teknologi mendorong pada perubahan kebutuhan dan kondisi baru yang menimbulkan berbagai tantangan dan permasalahan yang semakin kompleks. Sekolah sebagai pusat pendidikan dan kebudayaan harus tanggap terhadapa perubahan-perubahan itu, sehingga tidak hanya menghasilkan manusia yang berilmu , tetapi juga manusia yang berkaraekter. Dalam kaitan inilah Pendidikan Ilmu Pengetahuan Sosial memegang peranan yang sangat penting untuk memberikan pengertian dan pemahaman terhadap perubahan-perubahan masyarakat dengan berbagai tantangan dan permasalahannya, serta mampu mencari jalan keluarnya. Oleh karena itu IPS perlu diajaran dengan metode-metode dan teknik yang sesuai dengan perkembangan dan kebutuhan peserta didik, bukan saja menjejalkan dengan ilmu pengetahuan tetapi juga dengan nilai-nilai luhur budaya bangsan yang kini mulai tergerus, rasa kedisiplinan yang semakin merosot. Hal ini terlihat dari hasil observasi awal tentang nilai kedisiplinan yang dilakukan oleh peneliti saat proses pembelajaran mata pelajara IPS pada tanggal 7 Agustus 2017 khususnya pada materi menegnal tokoh sejarh pada masa hindu, budha dan islam di Indonesia, masih kurang disiplin, dan hasil belajar pada tes awal membuktikan masih dibawah ketuntasan maksimal (KKM) IPS di SDN Telaga Waru, Kec. Paraya kabupaten Lombok Tengah Tahun Pelajaran 2017/2018, yakni 70. Pada kenyataannya nilai peserta didik di bawah 70, yaitu 12 orang (sekitar $60 \%$ ) dari 31 orang yang terdiri dari 13 laki-laki dan 18 perempuan, dan sisanya 8 orang (sekitar $40 \%$ ) yang sudah berhasil mencapai KKM yang diharapkan. atas dasar ini maka metode penelitian yang akan diangkat adalah bagaimana "Penerapan Pendekatan VCT ( Value Clarification Teaching ) dapat Meningkatkan Kedisiplinan Dan Hasil Belajar IPS Pada Siswa Kelas V Telaga Waru Kec. Praya, Kab. Lombok Tengah Tahun Pelajaran 2017/2018
\end{abstract}

\section{Kata kunci; VCT ( Value Clarification Teaching ), kedisiplinan, hasil belajar}

\section{PENDAHULUAN}

Berdasarkan ketentuan umum sebagaimana tercantum dalam undang-undang nomoe 20 tahun 2003 tentang system pendidikan nasional Pendidikan nasional yang berdasarkan Pancasila dan Undang-undang Dasar Negara Republik Indonesia tahun 1945 mengamanatkan pemerintah mengusahakan dan menyelenggarakan satu sstem pendidikan ansional yang meningkatkan keimanan dan ketakwaan kepada Tuhan Yang Maha Esa, serta akhlak mulia dalam rangka mencerdaskan kehidupan bangsa (UU RI No. 20 Th.2003)

Implementasi Undang-undang nomor 20 tahun 2003 tentang system pendidikan nasional dijabarkan kedalam sejumlah peraturan antara lain PP No 19 tahun 2005 tentang standar nasional pendidikan. Dalam dokumen ini dibahas standar isi. Standar isi dikembangkan oleh Badan Standar Nasional Pendidikan ( BSNP) yang dibentuk berdasrkan PP Nomor 19 tahun 2005.

Peraturan Pemerintah Nomor 19 Tahun 2005 tentang Standar Nasional Pendidikan pasal 6 ayat (1) menyatakan bahwa kurikulum untuk jenis pendidikan umum, kejuruan, dan khusus pada jenjang pendidikan dasar dan menengah terdiri atas: salah satunya pada poin (b) kelompok mata pelajaran kewarganegaraan dan kepribadian, memuat cakupan: "Kelompok mata pelajaran kewarganegaraan dankepribadian dimaksudkan untuk peningkatan kesadaran dan wawasan peserta didik akan status, hak, dan kewajibannya dalam kehidupan bermasyarakat, berbangsa, dan bernegara, 
serta peningkatan kualitas dirinya sebagai manusia".

Kesadaran dan wawasan termasuk wawasan kebangsaan, jiwa dan patriotisme bela negara, penghargaan terhadap hak-hak asasi manusia, kemajemukan bangsa, pelestarian lingkungan hidup, kesetaraan gender, demokrasi, tanggung jawab sosial, ketaatan pada hukum, ketaatan membayar pajak, dan sikap serta perilaku anti korupsi, kolusi, dan nepotisme.

Kelompok mata pelajaran kewarganegaraan dan kepribadian yang termasuk didalamnya Ilmu pengetahuan social adalah semua bidang ilmu yang berkenaan dengan manusia dalam konteks sosialnya atau dengan kata lain semua bidang ilmu yang mempelajari manusia sebagai anggouta masyarakat.( Norma Mackenzie, 1975 dalam modul UT 2014)

Mengingat manusia dalam kontek sosial begitu luas maka pengajaran IPS di sekolah dasar dibatasi gejala dan masalah sosial kehidupan sehari-hari yang terdapat dilingkungan siswa. ruang lingkup tersebut harus selalu dihubungkan dengan dinamika masyarakat mulai dari masalah kehidupan , tempat tinggal, dan lingkungan keluarga, hingga lingkungan Negara tetangga, terutama mengenai kerjasama ekonomi, social, budaya, pendidikan kesehatan,

Memperhatiakn aspek-aspek dari ilmu sosial yang sangat luas maka untuk mendalaminya memerlukan perhatian yang sungguh-sungguh. Selain itu pembinaan perhatian tersebut harus dilakukan secara berkesinambungan mulai dari tingkat pendidikan dasar sampai ke tingkat pendidikan yang tertinggi.

Ilmu pengetahuan yang diajarkan pada pendidikan dasar dan menengah, menjadi dasar pengatar bagi mempelajari ilmu pengetahuan sosial/ studi sosial ataupun ilmu sosial di perguruan tinggi.

Dalam kegiatan pembelajaran ilmu penegtahuan sosial, siswa dapat dibawa langsung kedalam lingkungan alam dan masyarakat. Dengan lingkungan alam sekitar, siswa akan akrab dengan kondisi setempat sehingga mengetahui makna serta manfaat mata pelajaran ilmu pengetahuan sosial secara nyata.

Disamping itu, dengan mempelajari sosial/masyarakat, siswa secara langsung dapat mengamati dan mempelajari norma-norma/peraturan serta kebiasaankebiasaan baik yang berlaku dalam masyarakat sehingga siswa mendapat pengalaman langsung adanya hubungan timbal balik yang saling mempengaruhi anatar kehidupan pribadi dan masyarakat. Dengan akata lain manfaat yang diperoleh setelah mempelajari ilmu pengetahuan sosial disamping mempersiapkan diri untuk terjun ke masyarakat. Juga membentuk dirinya sebagai anggouta masyarakat yang baik dengan menaati aturan yang berlaku dan turut pula mengembangkan serta bermanfaat dalam pembentuakan karekter dan kedisiplinannya.

Berdasarkan hal tersebut, agar pengajaran IPS disekolah bermakna sebagai modal awal terjun di masyarakata sejak pendidikan dasar maka peneliti mengambil judul "Peningkatan kedisiplinan dan Hasil Belajar Peserta Didik dengan Menggunakan Pendekatan VCT ( Value Clarification Teaching ) pada Mata Pelajaran IPS V di SDN Telaga Waru Kec. Praya Tahun Pelajaran 2017/2018?

Alasan pengambilan judul tersebut diatas karena peneliti menyadari bahwa dengan sikap disiplin hasil belajar dan kesuksesan dalam segala hal dapat diraih.hanya orang-orang yang disiplin dan memegang nilai-nilai luhur yang dapat mencapai kesuksesan.

\section{Sasaran Tindakan}

Sasaran tindakan dalam penelitian ini adalah guru dan peserta didik SDN Telaga Waru Kec. Praya Tahun Pelajaran 2017/2018 semester ganjil tahun pelajaran 2017/2018 di Kelas V pada mata pelajaran IPS, yang berjumlah 31 orang yang terdiri dari 13 laki-laki dan 18 perempuan.

\section{Rumusan Masalah}

Bagaimanakah

Peningkatan kedisiplinan dan Hasil Belajar Peserta Didik dengan Menggunakan Pendekatan VCT (Value Clarification Teaching) pada Mata Pelajaran IPS V di SDN Telaga Waru Kec. Praya Tahun Pelajaran 2017/2018? 


\section{Tujuan Penelitian}

Untuk menegtahui Peningkatan Kedisiplinan dan Hasil Belajar Peserta Didik dengan Menggunakan Pendekatan VCT(Value Clarification Teaching ) pada Mata Pelajaran IPS Kelas V di SDN Telaga Waru Kec. Praya Tahun Pelajaran 2017/2018?

\section{Manfaat Penelitian}

Manfafat penelitian ini diharapkan dapat meningkatkan kedisilinan dan hasil belajar peserta didik pada mata pelajaran IPS di kelas V SDN Dasan Jontak tahun Pelajaran 2017/2018,dan sebaga salah satu refrensi untuk perbaikan pembelajaran dimasa yang

\section{KAJIAN PUSTAKA}

\section{Karaktristik Pembelajaran IPS di SD}

Kurikulum Pendidikan dasar tahun 2006 telah merumuskan bahwa telah merumuskan bahwa mata pelajaran Ilmu Pengetahuan Sosial (IPS) berfungsi sebagai ilmu pengetahuan untuk mengembangkan kemampuan dan sikap rasionala tentang gejala-gejala social serta kemampuan tentang perkembanagan masyrakat Indonesia dan masyrakat dunia dimasa lampau dan masa kini. Ilmu pengetahauan social (IPS) mempelajari berbagai kenyataan social dalam kehidupan sehari-hari yang bersumber dari imu bumi, ekonomi, sejarah, antripologi, dan tata Negara ( PDGK.4.106.5)

Berdasarkan kutipan diatas dapat ditafsirkan bahwa; materi pelajaran IPS diramu dari materi berbagai bidang IPS , atau apabila digunakan istilah pola piker Wesley (1968) merupakan simflikasi atau penyederhanaan ilmu-ilmu social untuk tujuan pendidikan. Matri ilmu penegtahuan sosial diseleksi dan diorganisasikan untuk mengembangkan kemampuan dan sikap rasional. Sedangkan menurut Banks (1977) IPS adalah mengembangkan kemampuan dan sikap rasional sebagai bekal untuk dapat melibatkan dari dalam masyrakat secara intelligent atau secara cerdas/nalar

Dengan demikian dapat ditarik kesimpulan bahwa karakteristik pembelajaran IPS di SD secara umum merupakan pendidikan kognitif sebgai dasar ikut serta dalam kegiatan social.artinya pusat utama perhatian pembelajaran IPS adalah pengembanagan murid sebagai pelaku sosial yang cerdas.

Untuk menjadi pelaku atau actor social yang cerdas tidak berarti hanya mengembangkan kecerdasan rasional, tetapi juga kecerdasan emosional (Golemen: 1966). Goleman ( 1966) menegaskan dua kecerdasn yang memiliki konstribusi terhadap keberhasilan seseorang dalam masyarakat masing-masing diperkirakan 20\% kecerdasan rasional dan $80 \%$ kecerdasan Emosional.

\section{Tinjauan Tentang Kedisiplinan}

\section{a. Pengertian disiplin}

Disiplin adalah suatu kondisi yang tercipta dan terbentuk melalui proses dari serangkaian perilaku yang menunjukkan nilai-nilai ketaatan, kepatuhan, kesetiaan, keteraturan dan ketertiban. Disiplin akan membuat seseorang tahu dan dapat membedakan hal-hal apa yang seharusnya dilakukan, yang wajib dilakukan, yang boleh dilakukan, yang tak sepatutnya dilakukan karena merupakan hal-hal yang dilarang.

Disiplin pada hakikatnya akan tumbuh dan terpancar dari hasil kesadaran manusia. Sebaliknya, disiplin yang tidak bersumber dari kesadaran hati nurani akan menghasilkan disiplin yang lemah dan tidak akan bertahan lama.

Disiplin secara luas, menurut conny diartikan sebagai semacam pengaruh yang dirancang untuk membantu anak mampu menghadapi tuntutan dari lingkungannya. Disiplin itu tumbuh dari kebutuhan untuk menjaga keseimbangan antara kecenderungan dan keinginan individu untuk berbuat sesuatu yang dapat dan ingin ia peroleh dari orang lain atau karena situasi dan kondisi tertentu, dengan batasan peraturan yang diperlukan terhadap dirinya atau lingkungan dimana ia hidup.( Conny Semiawan :2002.90)

Disiplin adalah patuh terhadap suatu peraturan dengan kesadaran sendiri untuk terciptanya tujuan itu.( Subari; 1994;164) Sedangkan menurut Amir Daien Indrakusuma menyebutkan bahwa disiplin merupakan kesediaan untuk mematuhi peraturan-peraturan dan larangan-larangan. 
Kepatuhan disini bukan hanya patuh karena adanya tekanan-tekanan dari luar, melainkan kepatuhan yang didasari oleh adanya kesadaran tentang nilai dan pentingnya peraturan- peraturan dan larangan tersebut. Disiplin adalah latihan pikiran, perasaan, kehendak dan watak, latihan pengembangan dan pengendalian perasaan, pikiran, kehendak dan watak untuk melahirkan ketaatan dan tingkah laku yang teratur.( Sukarna 1992; 104)

Dari kata disiplin muncullah kata kedisiplinan. Dalam penelitian ini, disiplin mendapat tambahan awalan ke- dan akhiran -an (kedisiplinan). Menurut W.J.S Poerwadarminta, kedisiplinan berasal dari kata disiplin yang mendapat konfiks ke - an yang mempunyai arti latihan batin dan watak dengan maksud supaya segala perbuatannya selalu mentaati tata tertib( Purwadarminta; 1997; 254) Kedisiplinan adalah ketaatan terhadap aturan atau tata tertib. ${ }^{15}$ tata tertib berarti separangkat peraturan yang berlaku untuk menciptakan kondisi yang tertib dan teratur. ${ }^{16}$ Jadi kedisiplinan merupakan hal mentaati tata tertib disegala aspek kehidupan, baik agama, budaya, pergaulan, sekolah, dan lain- lain. Dengan kata lain, kedisiplinan merupakan kondisi yang tercipta dan terbentuk melalui proses dari serangkaian perilaku individu yang menunjukkan nilai-nilai ketaatan, kesetiaan, keteraturan dan ketertiban.

Keberhasilan dalam suatu usaha atau dalam mencapai cita-cita akan tergantung kepada sikap disiplinnya. Orang yang berdisiplin akan berperilaku apa yang seharusnya diperbuat, tidak mengada-ada, tidak dilebih-lebihkan tetapi juga tidak dikurangi dari keadaan yang sebenarnya. Diam tepat pada pijakannya, melangkah tepat gerakannya, melaju sesuai arahnya.

Sikap disiplin dapat dilakukan untuk setiap perilaku, seperti disiplin dalam belajar, disiplin dalam beribadah, disiplin dalam bekerja, dan disiplin dalam beraktivitas lainnya.

Dari beberapa definisi diatas, menunjukkan bahwa kedisiplinan merupakan ketaatan dan kepatuhan pada peraturan yang dilakukan dengan rasa senang hati, bukan karena dipaksa atau terpaksa.

\section{b. Tujuan Kedisiplinan}

Adapun tujuan kedisiplinan menurut Elsbree dalam bukunya "Leadership In Elementary School Administration And Supervision" yang dikutip oleh Drs. Piet A. Sahertian menyatakan: He should accept the phylosopy that discipline any action have two pourpose, tujuan tersebut adalah:

- Menolong anaknya menjadi matang pribadinya dan berubah dari sifat ketergantungan kearah tidak ketergantungan.

- Mencegah timbulnya persoalan-persoalan disiplin dan menciptakan situasi dan kondisi dalam belajar mengajar agar mengikuti segala peraturan yang ada dengan penuh perhatian( Bild Gard, dalam Cony 1997,98).

Jadi dapat disimpulkan bahwa tujuan kedisiplinan adalah dalam rangka untuk menolong dan membimbing anak agar matang pribadinya dan dapat meningkatkan kehidupan mental yang sehat sehingga memberikan cukup kebebasan bagi mereka untuk berbuat secara bertanggung jawab sesuai dengan kemampuan yang ada pada dirinya.

\section{Faktor-faktor Kedisiplinan}

Dalam rangka membina dan meningkatkan kedisiplinan siswa dalam melaksanakan ibadah shalat terutama di lingkungan sekolah, perlu diperhatikan unsur-unsur yang mempengaruhi terhadap kedisiplinan siswa gar disiplin dapat terwujud dalam perilaku siswa. Adapun faktor-faktor pembentukan perilaku yang termasuk didalamnya perilaku disiplin adalah:

\section{Faktor Genetik}

Yang dimaksud faktor genetik adalah segala hal yang dibawa oleh anak sejak lahir sebagai warisan dari orang tuanya. Menurut Mahfud Salahuddin, faktor genetik atau hereditas adalah kecenderungan untuk tumbuh dan berkembang bagi manusia, menurut pola-pola, ciri-ciri, serta sifat-sifat tertentu dari satu generasi ke generasi berikutnya. $^{18}$ 
Pembentukan perilaku manusia dapat dipengaruhi oleh limpahan orang tua kepada keturunannya karena faktor ini meski tidak kuat, namun merupakan bentuk dasar dari perilaku seseorang. Demikian halnya dengan kedisiplinan, sangatlah mungkin kedisiplinan tersebut dipengaruhi oleh watak yang dibawa seseorang sejak lahir.

\section{Faktor Lingkungan}

Lingkungan mempunyai peranan yang sangat penting terhadap kedisiplinan karena perkembangan seseorang tidak terlepas dari peranan lingkungan, disamping faktor pembawaan, kedisiplinan juga dipengaruhi oleh situasi dan kondisi dimana ia berada. Sejak lahir manusia berinteraksi dengan lingkungan, mempengaruhi dan dipengaruhi oleh lingkungan dimana ia tinggal. Fungsinya kepribadian seseorang merupakan hasil dari interaksi antara dirinya dan lingkungan. Baik lingkungan fisik maupun lingkungan psikologis.

\section{Faktor Pendidikan}

Menurut Marimba, pendidikan adalah bimbingan atau pimpinan secara sadar oleh si pendidik terhadap perkembangan jasmani dan rohani si terdidik menuju terbentuknya kepribadian yang utama. ${ }^{19}$ Dalam sasaran pendidikan tidak semata-mata pengalihan pengetahuan dan keterampilan saja, salah satu bagian yang teramat penting adalah pembinaan watak. Pembinaan watak merupakan bagian integral dari pendidikan. Oleh sebab itu bahwa pendidikan memainkan peranan penting dalam pembentukan perilaku seseorang, termasuk didalamnya perilaku disiplin.

\section{Faktor Pengalaman}

Pengalaman disini adalah keseluruhan peristiwa yang pernah dialami oleh seseorang baik secara langsung maupun tidak langsung dalam perjalanan hidupnya. Pengalaman seseorang juga mempunyai pengaruh terhadap pembentukan watak termasuk kedisiplinan. ${ }^{20}$

\section{Tinjauan Tentang Pendekatan VCT (Value Clarification Teaching )}

Value menurut Doley dan Copaldi ( 1965: 31 dalam modul UT pembelajaran IPS di SD ,5.20) diterjemahkan menjadi nilai memiliki dua sisi yakni sebagai kata benda dan kata kerja. Sebagai kata benda nilai mempunyai dua pengertian, pertama sebagai obyek sesuatu dianggap suatu nilai, apabila memiliki kualitas kebaikan atau harga( goodness atau worth). Misalnya, gula manis, gadis cantik, orang alim, udara sejuk, manis, cantik ,alim, sejuk itulah nilai. Kedua, sebagai pengamat suatu hal dianggap bernilai atau memiliki nilai apabila dilihat dari pikiran seseorang sebagai memilki, kualitas atau harga. Contoh gadis itu dianggap cantik apabila dilihat dari pandangan orang lain.

Jadi dengan kata lain, sesuatu dapat dinilai memiliki value atau harga apabila memang hal itu memiliki kualitas kebaikan dan dilihat oleh pengamat sebagai hal yangbaik. Dilain pihak, sebagai kata kerja menilai diartikan sebagai prilaku mental untuk member atau mengatakan sesuatu sebagai memiliki kualitas kebaikan. Misalnya menilai barang yang artinya melihat apakah barang itu berguna atau tidak, baik atau tudak.

Dalam pengertian teknis, seperti dikmukan oleh Milton Rokeach dalam Banks (1977:407-408) nilai adalah suatu jenis kepercayaan yang ada dalam keseluruhan system kepercayaan seseorang,mengenal baimana seseorang seharunya atau tidak seharusnya berprilaku atau perlu tidak sesuatu dicapai. Nilai juga merupakan ukuran untuk menetapkan baik dan buruk. Nilai dapat dibangun dalam satu tatanan atau system yang bisa merupakan system nilai perorangan atau kelompok . contohnya setiap orang mempunyai nilai relegi yang terbentuk dari pengetahuan pemahaman pelaksanaan dan komitmen seseorang pada agama yang dianutnya dengan baik. Negara kita Republik Indonesia memiliki system nilai Pancasila dan UUD 1945 yang merupakan tatanan nilai yang dipahami dan dihayati dalam rangka berkehidupan dan berbangsa serta bernegara. System nilai ini dapat juga sebagai tatanan kebaikan yang diyakini dan dilaksanakan.

\section{Langkah-langkah Penerapan VCT (Value} Clarification Teaching )

Klarifikasi nilai atau value Clarification menitik beratkan pada lankah sistematis dalam menghayati, memahami, dan melaksanakan nilai. Adapun langkah-langkah penerapannya sebagai berikut: 
a) Bangga atas nilai dan prilaku

1. Menunjukkan rasa senang dan bangga

2. Mengatakan nilai pada orang lain

b) Memilih nilai dan prilaku

1. Memilih dari berbagai kemungkinan

2. Memilih setelah mengujinya

3. Memilih dengan bebas

c) Bertindak atas dasar pilihat itu

1. Bertindak atau berprilaku

2. Bertindak sesuai pola secara tetap/ konsisten

\section{Tinjauan Tentang Prestasi Belajar}

Prestasi belajar secara harfiah terdiri dari dua rangkaian kata yaitu prestasi dan belajar. Dalam Kamus Bahasa Indonesia, Poerwadarminto menjelaskan bahwa, " Prestasi adalah hasil yang dicapai " ( 1985 : 108 ) secara lebih jelasnya prestasi adalah hasil atau kemampuan yang telah diperoleh seseorang. Sedangkan yang dimaksud dengan belajar adalah usaha yang dilakukan untuk menambah kemampuan.

Menurut pendapat Sumadi Suryabrata (1984:253) dalam bukunya Psikologi Pendidikan, mengenai prestasi belajar dijelaskan sebagai berikut; (1) Bahwa belajar itu membawa perubahan (dalam arti behavior changes, actual maupun potensial ). (2)Bahwa perubahan itu terjadi karena usaha dengan sengaja

Berdasarkan uraian di atas pengertian prestasi belajar adalah hasil belajar mengajar atau latihan. Hasil belajar ini biasanya diukur melalui evaluasi belajar yang dilakukan oleh guru. Pemberian tes ini biasanya diukur sesuai dengan tingkatannya.

\section{Jenis-Jenis Prestasi}

Berdasarkan tujuan yang hendak dicapai, prestasi belajar menurut Sumadi Suryabrata ( $1983: 83$ ) dapat dibagi menjadi 3 yaitu : (1)Prestasi belajar yang berupa kemampuan terhadap penguasaan ilmu pengetahuan yang diajarkan (2) Untuk mengetahui kekurangan dan kelemahan-kelemahan yang terdapat pada anak didik maupun pendidikan dalam pelaksanaan proses belajar mengajar. (3) Untuk menentukan langkah-langkah yang bisa diambil dalam. Menentukan program belajar mengajar yang berikutnya.

\section{Faktor-Faktor yang mempengaruhi Belajar.}

Sebagaimana kita ketahui bahwa kemampuan anak dalam menyerap Pelajaran tidaklah sama antara satu dengan lainnya. Itulah sebenarnya masuk diantara hal yang menyebabkan perbedaan hasil belajar anak. Disamping itu prestasi belajar anak tidak hanya dipengaruhi oleh lingkungan sekolah saja akan tetapi lingkungan dimana dia akan tinggal juga turut menentukan hasil pelajaran. Secara global faktor-faktor yang mempengaruhi siswa menurut Muffibbin Syah ( 1995..132 ), terdiri dari : (Faktor Internal ( fa1) ktor dari dalam siswa ) yakni kondisi lingkungan disekitar siswa. (2) Faktor Eksternal ( faktor dari luar siswa ) yakni kondisi lingkungan disekitar siswa. (3) Faktor pendekatan belajar ( approach to learning ) yakni jelas upaya belajar siswa yang meliputi strategi dan metode yang digunakan siswa untuk melakukan kegiatan pembelajaran materi-materi pelajaran.

\section{METODE PENELITIAN \\ Seting Penelitian}

Penelitian ini merupakan penelitian tindakan (action research), karena penelitian dilakukan untuk memecahkan masalah pembelajaran di kelas. Penelitian ini juga termasuk penelitian deskriptif, sebab menggambarkan bagaimana suatu teknik pembelajaran diterapkan dan bagaimana hasil yang diinginkan dapat dicapai.

Menurut Sukidin dkk. (2002:54) ada 4 macam bentuk penelitian tindakan, yaitu: (1) penelitian tindakan guru sebagai peneliti, (2) penelitian tindakan kolaboratif, (3) penelitian tindakan simultan terintegratif, dan (4) penelitian tindakan sosial eksperimental.

$$
\text { Penelitian ini mengacu pada }
$$
perbaikan pembelajaran yang berkesinambungan. Kemmis dan Taggart (1988:14) menyatakan bahwa model penelitian tindakan adalah berbentuk spiral. Tahapan penelitian tindakan pada suatu siklus meliputi perencanaan atau pelaksanaan observasi dan refleksi. Siklus ini berlanjut dan akan dihentikan jika sesuai dengan kebutuhan dan dirasa sudah cukup.

\section{Desain Penelitian}


Sesuai dengan jenis penelitian yang dipilih, yaitu penelitian tindakan, maka penelitian ini menggunakan model penelitian tindakan dari Kemmis dan Taggart (1988:14), yaitu berbentuk spiral dari siklus yang satu ke siklus yang berikutnya. Setiap siklus meliputi planning (rencana), action (tindakan), observation (pengamatan), dan reflection (refleksi). Langkah pada siklus berikutnya adalah perncanaan yang sudah direvisi, tindakan, pengamatan, dan refleksi. Sebelum masuk pada siklus 1 dilakukan tindakan pendahuluan yang berupa identifikasi permasalahan. Siklus spiral dari tahap-tahap penelitian tindakan kelas dapat dilihat pada gambar berikut:

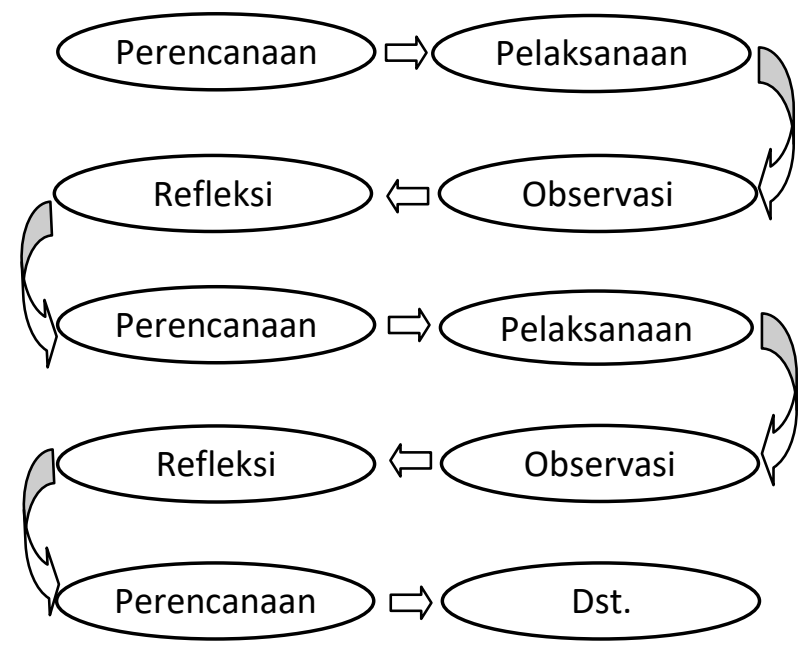

Gambar 3.1 Alur PTK

Penelitian ini dilaksanakan sebanyak dua siklus/putaran.Observasi dibagi dalam dua putaran, yaitu putaran 1 , dan 2 , dimana masing putaran dikenai perlakuan yang sama (alur kegiatan yang sama) dan membahas satu sub pokok bahasan yang diakhiri dengan tes formatif di akhir masing putaran. Dibuat dalam dua putaran dimaksudkan untuk memperbaiki sistem pengajaran yang telah dilaksanakan.

\section{Tempat dan Waktu Penelitian}

Penelitian ini dilaksanakan di SDN Telaga Waru Kec. Praya semester pertama tahun pelajaran 2017/2018 pada siswa kelas V yang terdiri dari 13 orang laki-laki dan 18 orang perempuan.

\section{Prosedur Penelitian}

Penelitian ini dilaksanakan melalui 4 tahap, yaitu, (1) tahap perencanaan, (2) tahap persiapan, dan (3) tahap pelaksanaan, (4) tahap pengolahan data,

\section{Teknik Analisis Data}

Untuk mengetahui keefektivan suatu metode dalam kegiatan pembelajaran perlu diadakan analisis data. Pada penelitian ini menggunakan teknik analisis dekriptif kualitatif, yaitu suatu metode penelitian yang bersifat menggambarkan kenyataan atau fakta sesuai dengan data yang diperoleh dengan tujuan untuk mengetahui hasil belajar yang dicapai siswa, juga untuk memperoleh respon siswa terhadap kegiatan pembelajaran serta aktivitas siswa selama proses pembelajaran.

Untuk menganalisi tingkat keberhasilan atau peresentase keberhasilan siswa setelah proses belajar mengajar setiap siklus nya dilakukan dengan cara memberikan evaluasi berupa soal tes tertulis paa setiap akhir siklus .

Analisi ini dihitung dengan menggunakan statistik sederhana yaitu :

\section{Untuk menilai ulangan atau tes formatif}

Peneliti melakukan penjumlahan nilai yang diperoleh siswa, yang selanjutnya dibagi dengan jumlah siswa yang ada di kelas tersebut sehingga diperoleh rata-rata tes formatif dapat dirumuskan :

$$
\begin{aligned}
& \overline{\mathrm{X}}=\frac{\sum x}{\Sigma \mathrm{N}} \\
& \text { Dengan } \quad \text { : } \\
& \mathrm{X} \quad=\text { Nilai rata-rata } \\
& \sum \mathrm{X} \quad=\text { Jumla semua nilai siswa } \\
& \sum \mathrm{N} \quad=\text { Jumlah siswa }
\end{aligned}
$$

\section{Untuk ketuntasan belajar}

Ada dua kategori ketuntasan belajar yaitu secaraa perorangan dan secaraa klasikal. Berdasarkan petunjuk pelaksanaan belajar mengajar kurikulum 1994 yaitu seorang siswa telah tuntas belajar bila telah mencapai skor $65 \%$ atau nilai 65 , dan kelas disebut tuntas belajar apa bila di kelas tersebut terdapat $85 \%$ yang telah mencapai daya serap lebih dari atau sama dengan 65\%. Untuk menghitung presentase ketuntasan belajar digunakan rumus sebagai berikut :

$$
\mathrm{P}=\frac{\Sigma \text { Siswa.yang.tuntas.belajar }}{\Sigma \text { Siswa }} \times 100 \%
$$

\section{Untuk lembar observasi}


a. Lembar observasi pengelola Pendekatan VCT

Untuk menghitung lembar observasi pengelolaan Pendekatan VCT digunakan rumus sebagai berikut :

$\mathrm{X}=\frac{P 1+P 2}{2}$

Dimana $\mathrm{P} 1=$ Pengamat 1 dan $\mathrm{P} 2=$ Pengamat 2

b. Lembar observasi aktifitas guru dan siswa Untuk menghitung lembar observasi aktifitas guru dan siswa digunakan rumus sebagai berikut :

$\%=\frac{x}{\Sigma x} \times 100 \%$ dengan

$\mathrm{X}=-\frac{\text { Jumah.hasil.pengama } \tan }{\text { Jumlah.pengama } \tan }=$

$\frac{P 1+P 2}{2}$

Dimana: $\%=$

Presentase

pengamatan

$$
\begin{array}{ll}
\mathrm{X} & =\text { Rata-rata } \\
\sum \mathrm{x} & =\text { Jumlah rata-rata } \\
\mathrm{P} 1 & =\text { Pengamat } 1 \\
\mathrm{P} 2 & =\text { Pengamat } 2
\end{array}
$$

\section{HASIL PENELITIAN}

\section{Diskripsi Hasil Penelitian}

Data penelitian yang diperoleh adalah data observasi berupa pengamatan pengelolaan belajar aktif dan pengamatan aktivitas siswa dan guru pada akhir pembelajaran, dan data tes formatif siswa pada setiap siklus.

Data lembar observasi diambil dari dua pengamatan yaitu data pengamatan pengelolaan pembelajaran Pendekatan VCT yang digunakan untuk mengetahui pengaruh penerapan pendekatan VCT dalam meningkatkan kedisiplinan dan hasil belajar IPS

Data tes formatif untuk mengetahui peningkatan hasil belajar siswa setelah diterapkan pendekatan VCT

\section{Pembahasan Hasil Peneltian}

\section{Siklus I}

Untuk memperoleh gambaran dari hail penelitian diperlukan data. Data tersebut adalah sejumlah fakta yang digunakan sebagai sumber atau masukan untuk menentukan kesimpulan atau keputusan yang diambil yang menjadi topik pengamatan adalah kegiatan siswa. Kegiatan guru dan hasil pembelajaran siswa pada mata pelajaran IPS tentang menganal tokoh sejarah pada masa hindu, budha dan islam di Indonesia.

Setelah diadakan penelitian pada siklus 1 masih belum menunjukkan hasil yang memuaskan, bahwa kemampuan siswa dalam memahami materi pembelajaran yaitu menganal tokoh sejarah pada masa hindu, budha dan islam di Indonesia.

Prestasi belajar siswa dan aktifitas siswa serta pemahaman terhadap materi pelajaran belum maksimal dari hasil tes di peroleh 17 siswa dari 31 orang siswa belum mencapai standar KKM yang di tetapkan di SDN Telaga Waru Kec. Praya yaitu 70 untuk Mata pelajaran IPS berdasarkan Kurikulum tahun Pelajaran 2017/2018 ( KTSP SDN Telaga Waru )

Tabel 3. Hasil Penilain siklus 1

\begin{tabular}{|c|l|c|c|}
\hline No & Nama siswa & $\begin{array}{c}\text { Jenis } \\
\text { Kelamin }\end{array}$ & Nilai \\
\hline 1 & RA & L & 60 \\
\hline 2 & L.S & L & 60 \\
\hline 3 & I & P & 70 \\
\hline 4 & NW & P & 65 \\
\hline 5 & WH & L & 65 \\
\hline 6 & IP & P & 75 \\
\hline 7 & AA & P & 60 \\
\hline 8 & RS & L & 75 \\
\hline 9 & MH & P & 60 \\
\hline 10 & MI & P & 70 \\
\hline 11 & Mr & P & 75 \\
\hline 12 & Sci & P & 70 \\
\hline 13 & Sni & L & 75 \\
\hline 14 & IA & L & 50 \\
\hline 15 & DM & P & 60 \\
\hline 16 & AL & L & 60 \\
\hline 17 & Az & P & 60 \\
\hline 18 & RN & P & 70 \\
\hline 19 & Hh & P & 60 \\
\hline 20 & Nh & P & 60 \\
\hline 21 & Ww & P & 70 \\
\hline 22 & RF & P & 65 \\
\hline 23 & RAn & P & 60 \\
\hline 24 & HI & 65 \\
\hline 25 & AS & A & 60 \\
\hline 26 & AA & HZ & \\
\hline 27 & & & 70 \\
\hline
\end{tabular}




\begin{tabular}{|c|l|c|c|}
\hline 28 & Wr & L & 70 \\
\hline 29 & MD & L & 70 \\
\hline 30 & SH & P & 70 \\
\hline 31 & AL & P & 60 \\
\hline & Jumlah & 31 org & 2030 \\
\hline & Rata-rata & 14 & 65.5 \\
\hline $\begin{array}{l}\text { Jumlah siswa } \\
\text { tuntas }\end{array}$ & $45,16 \%$ & \\
\hline $\begin{array}{l}\text { Prosentase } \\
\text { Ketuntasan kelas }\end{array}$ & & \\
\hline
\end{tabular}

Dari pengolahan nilai kegiatan pembelajaran pada siklus I aspek-aspek yang mendapatkan kriteria kurang baik adalah memotivasi siswa, menyampaikan tujuan pembelajaran, pengelolaan waktu, dan siswa antusias. Keempat aspek yang mendapat penilaian kurang baik di atas, merupakan suatu kelemahan yang terjadi pada siklus I. Dan akan dijadikan bahan kajian untuk refleksi dan revisi yang akan dilakukan pada siklus II.

Berdasarkan hasil analisis pengelolaan aktivitas guru dan siswa hal yang paling dominan pada siklus I adalah membimbing dan mengamati siswa dalam menemukan konsep yaitu $21,7 \%$. Aktivitas lain yang persentasenya cukup besar adalah memberi umpan balik/evaluasi/tanya jawab dan menjelaskan materi yang sulit yaitu masing-masing sebesar 18,3\% dan 13,3\%. Sedangkan aktivitas siswa yang paling dominan adalah mengerjakan/memperhatikan penjelasan guru yaitu 22,5\%. Aktivitas lain yang persentasenya cukup besar adalah bekerja dengan sesama anggota kelompok, diskusi antar siswa/antara siswa dengan guru, dan membaca buku yaitu masing-masing $18,7 \% 14,4$ dan $11,5 \%$.

Pada siklus I, secara garis besar kegiatan belajar mengajar dengan merapkan metode pengajaran terarah sudah dilaksanakan dengan baik, walaupun peran guru masih cukup dominan untuk memberikan penjelasan dan arahan karena model tersebut masih dirasakan baru oleh siswa.

Berikutnya adalah rekapitulasi hasil tes formatif siswa seperti terlihat pada tabel berikut.
Tabel 4.3. Rekapitulasi Hasil Tes Formatif Siswa Pada Siklus I

\begin{tabular}{|c|c|c|}
\hline No & Uraian & $\begin{array}{c}\text { Hasil } \\
\text { Siklus I }\end{array}$ \\
\hline 1 & Nilai rata-rata tes formatif & 65,5 \\
\hline 2 & $\begin{array}{l}\text { Jumlah siswa yang tuntas } \\
\text { belajar }\end{array}$ & 14 \\
\hline 3 & $\begin{array}{l}\text { Persentase ketuntasan } \\
\text { belajar }\end{array}$ & 45,16 \\
\hline
\end{tabular}

Dari tabel di atas dapat dijelaskan bahwa dengan menerapkan pendekatan VCT diperoleh nilai rata-rata prestasi belajar siswa adalah 65,5 dan ketuntasan belajar mencapai $45,16 \%$ atau ada 14 siswa dari 31 siswa sudah tuntas belajar. Hasil tersebut menunjukkan bahwa pada siklus pertama secara klasikal siswa belum tuntas belajar, karena siswa yang memperoleh nilai $\geq 70$ hanya sebesar 45,16\% lebih kecil dari persentase ketuntasan yang dikehendaki yaitu sebesar $85 \%$. Hal ini disebabkan karena siswa masih merasa baru dan belum mengerti apa yang dimaksudkan dan digunakan guru dengan menerapkan pendekatan pembelajaran reflektiv

\section{c. Refleksi}

Dalam pelaksanaan kegiatan belajar mengajar diperoleh informasi dari hasil pengamatan sebagai berikut:

1) Guru kurang baik dalam memotivasi siswa dan dalam menyampaikan tujuan pembelajaran

2) Guru kurang baik dalam pengelolaan waktu

3) Siswa kurang begitu antusias selama pembelajaran berlangsung.

Pelaksanaan kegiatan belajar mengajar pada siklus I ini masih terdapat kekurangan, sehingga perlu adanya refisi untuk dilakukan pada siklus berikutnya.

1) Guru perlu lebih terampil dalam memotivasi siswa dan lebih jelas dalam menyampaikan tujuan pembelajaran. Dimana siswa diajak untuk terlibat langsung dalam setiap kegiatan yang akan dilakukan.

2) Guru perlu mendistribusikan waktu secara baik dengan menambahkan informasiinformasi yang dirasa perlu dan memberi catatan 
3) Guru harus lebih terampil dan bersemangat dalam memotivasi siswa sehingga lebih antusias.

\section{Siklus II}

\section{a. Tahap perencanaan}

Pada tahap ini peneliti mempersiapkan perangkat pembelajaran yang terdiri dari Rencana Perbaiakan Pembelajaran 2, LKS, 2, soal tes formatif 2 dan alat-alat pengajaran yang mendukung.

\section{b. Tahap kegiatan dan pelaksanaan}

Pelaksanaan kegiatan belajar mengajar untuk siklus II dilaksanakan pada tanggal 9 September 2017 di kelas dengan jumlah siswa 31 siswa. Dalam hal ini peneliti bertindak sebagai Pengajar sekaligus sebagai peneliti dengan dibantu oleh salah seorang guru senior. Adapun proses belajar mengajar mengacu pada Rencana Perbaiakan Pembelajaran dengan memperhatikan revisi pada siklus I, sehingga kesalahan atau kekurangan pada siklus I tidak terulang lagi pada siklus 2

\section{c.Pengamatan}

Dilaksanakan bersamaan dengan pelaksanaan belajar mengajar. Pada akhir proses belajar mengajar siswa diberi tes formatif 2 dengan tujuan untuk mengetahui tingkat keberhasilan siswa dalam proses belajar mengajar yang telah dilakukan. Instrumen yang digunakan adalah tes formatif 2

Dilaksanakan bersamaan dengan pelaksanaan belajar mengajar. Pada akhir proses belajar mengajar siswa diberi tes formatif 2 dengan tujuan untuk mengetahui tingkat keberhasilan siswa dalam proses belajar mengajar yang telah dilakukan. Instrumen yang digunakan adalah tes formatif 2. Adapun data hasil penelitian pada siklus 2 adalah sebagai berikut:

Tabel 4.3. Hasil Penilain siklus 2

\begin{tabular}{|c|l|c|c|}
\hline No & \multicolumn{1}{|c|}{ Nama siswa } & $\begin{array}{c}\text { Jenis } \\
\text { Kelamin }\end{array}$ & Nilai \\
\hline 1 & RA & L & 70 \\
\hline 2 & L.S & L & 69 \\
\hline 3 & I & P & 70 \\
\hline 4 & NW & P & 75 \\
\hline 5 & WH & L & 80 \\
\hline 6 & IP & P & 70 \\
\hline 7 & AA & P & 82 \\
\hline
\end{tabular}

\begin{tabular}{|c|l|c|c|}
\hline 8 & RS & L & 70 \\
\hline 9 & MH & L & 70 \\
\hline 10 & MI & P & 65 \\
\hline 11 & Mr & P & 70 \\
\hline 12 & Sci & P & 70 \\
\hline 13 & Sni & P & 75 \\
\hline 14 & IA & L & 75 \\
\hline 15 & DM & L & 80 \\
\hline 16 & AL & P & 70 \\
\hline 17 & Az & P & 69 \\
\hline 18 & RN & P & 85 \\
\hline 19 & Hh & P & 75 \\
\hline 20 & Nh & P & 75 \\
\hline 21 & Ww & P & 70 \\
\hline 22 & RF & P & 88 \\
\hline 23 & RAn & L & 70 \\
\hline 24 & HI & P & 75 \\
\hline 25 & AS & L & 75 \\
\hline 26 & AA & P & 80 \\
\hline 27 & HZ & L & 75 \\
\hline 28 & Wr & L & 70 \\
\hline 29 & MD & P & 70 \\
\hline 30 & SH & 31 org & 2293 \\
\hline 31 & AL & $90,32 \%$ & 74,0 \\
\hline & Jumlah & & \\
\hline & Rata-rata & & \\
\hline Jumlah siswa tuntas & 28 orang & \\
\hline Prosentase ketuntasan \\
kelas & 90,15 \\
\hline
\end{tabular}

Dari hasil analisi pada pengolahan pembelajaran , tampak aspek-aspek yang diamati pada kegiatan belajar mengajar (siklus II) yang dilaksanakan oleh guru dengan menerapkan pendekata VCT dalam pengelolaan pembelajaran mendapatkan penilaian yang "cukup baik" dari pengamat. Maksudnya dari seluruh penilaian tidak terdapat nilai kurang. Namum demikian penilaian tersebut belum merupakan hasil yang optimal, untuk itu ada beberapa aspek yang perlu mendapatkan perhatian untuk penyempurnaan penerapan pembelajaran selanjutnya. Aspek-aspek tersebut adalah memotivasi siswa, membimbing siswa merumuskan kesimpulan/ menemukan konsep, dan pengelolaan waktu.

Dengan penyempurnaan aspek-aspek di atas dalam penerapan metode pengajaran terarah diharapkan siswa dapat 
menyimpulkan apa yang telah mereka pelajari dan mengemukakan pendapatnya sehingga mereka akan lebih memahami tentang apa yang telah mereka lakukan.

Berdasarkan hasil pengolahan terhadap aktivitas guru dan siswa poin yang paling dominan pada siklus II adalah membimbing dan mengamati siswa dalam menemukan konsep yaitu $25 \%$. Jika dibandingkan dengan siklus I, aktivitas ini mengalami peningkatan. Aktivitas guru yang mengalami penurunan adalah memberi umpan balik/evaluasi/tanya jawab (16,6\%), menjelaskan materi yang sulit $(11,7)$. Meminta siwa mendiskusikan dan menyajikan hasil kegiatan $(8,2 \%)$, dan membimbing siswa merangkum pelajaran $(6,7 \%)$.

Sedangkan untuk aktivitas siswa yang paling dominan pada siklus II adalah Bekerja dengan sesama anggota kelompok yaitu (21\%). Jika dibandingkan dengan siklus I, aktivitas ini mengalami peningkatan. Aktivitas siswa yang mengalami penurunan adalah mendengarkan/ memperhatikan penjelasan guru (17,9\%). Diskusi antar siswa/antara siswa dengan guru $(13,8 \%)$, menulis yang relevan dengan $\operatorname{KBM}(7,7 \%)$ dan merangkum pembelajaran $(6,7 \%)$. Adapun aktivitas siswa yang mengalami peningkatan adalah membaca buku $(12,1 \%)$, menyajikan hasil pembelajaran $(4,6 \%)$, menanggapi/ mengajukan pertanyaan/ ide $(5,4 \%)$, dan mengerjakan tes evaluasi $(10,8 \%)$.

Berikutnya adalah rekapitulasi hasil tes formatif siswa terlihat pada tabel berikut.

Tabel 4.6. Rekapitulasi Hasil Tes Formatif

Siswa Pada Siklus II

\begin{tabular}{|c|l|c|}
\hline No & \multicolumn{1}{|c|}{ Uraian } & $\begin{array}{c}\text { Hasil } \\
\text { Siklus II }\end{array}$ \\
\hline 1 & $\begin{array}{l}\text { Nilai rata-rata tes formatif } \\
2\end{array}$ & $\begin{array}{l}\text { Jumlah siswa yang tuntas } \\
\text { belajar }\end{array}$ \\
3 & $\begin{array}{l}\text { Persentase ketuntasan } \\
\text { belajar }\end{array}$ & 90,32 \\
\hline
\end{tabular}

Dari tabel di atas diperoleh nilai ratarata prestasi belajar siswa adalah 74 dan ketuntasan belajar mencapai $90,32 \%$ atau ada 28 siswa dari 23 siswa sudah tuntas belajar. Hasil ini menunjukkan bahwa pada siklus II ini ketuntasan belajar secara klasikal telah mengalami peningkatan sebesar 48,16 dari siklus I. Adanya peningkatan hasil belajar siswa ini karena setelah guru menginformasikan bahwa setiap akhir pelajaran akan selalu diadakan tes sehingga siswa termotivasi untuk belajar. Selain itu siswa juga sudah mulai mengerti apa yang dimaksudkan dan dinginkan guru dengan menerapkan pembelajaran VCT.

c. Refleksi

Dalam pelaksanaan kegiatan belajar diperoleh informasi dari hasil pengamatan sebagai berikut:

1) Memotivasi siswa

2) Membimbing siswa merumuskan kesimpulan/menemukan konsep

3) Pengelolaan waktu.

Karena menunjukkan peningkatan hasil dan proses pembelajaran pada siklus II sangat signipikan maka perbaikan pembelajaran dihentikan sampai siklus 2 .

\section{B.Pembahasan Hasil Penelitian}

1. Ketuntasan Hasil belajar Siswa

Melalui hasil penelitian ini menunjukkan bahwa pendekatan pembelajaran VCT memiliki dampak positif dalam meningkatkan kreatifitas dan hasil belajar siswa. Hal ini dapat dilihat dari semakin mantapnya pemahaman siswa terhadap materi yang disampaikan guru (ketuntasan belajar meningkat dari siklus I, dan II) yaitu masing-masing 45.16\%, dan 90,32\%. Pada siklus II ketuntasan belajar siswa secara klasikal telah tercapai.

2. Kemampuan Guru dalam Mengelola Pembelajaran

Berdasarkan analisis data, diperoleh aktivitas siswa dalam proses belajar aktif dalam setiap siklus mengalami peningkatan. Hal ini berdampak positif terhadap prestasi belajar siswa yaitu dapat ditunjukkan dengan meningkatnya nilai rata-rata siswa pada setiap siklus yang terus mengalami peningkatan.

3. Aktivitas Guru dan Siswa Dalam Pembelajaran

Berdasarkan analisis data, diperoleh aktivitas siswa dalam proses pembelajaran IPS dengan pokok bahasan tokoh-tokoh perjuanagan pada masa hindu, budha dan islam dengan pendekatan VCT yang paling dominant adalah bekerja dengan 
menggunakan

alat/media, mendengarkan/memperhatikan penjelasan guru, dan diskusi antar siswa/antara siswa dengan guru. Jadi dapat dikatakan bahwa aktivitas isiwa dapat dikategorikan aktif.

Sedangkan untuk aktivitas guru selama pembelajaran telah melaksanakan langkah-langkah belajar aktif dengan baik. Hal ini terlihat dari aktivitas guru yang muncul di antaranya aktivitas membimbing dan mengamati siswa dalam mengerjakan kegiatan LKS/menemukan konsep, menjelaskan materi yang tidak dimengerti, memberi umpan balik/evaluasi/tanya jawab dimana prosentase untuk aktivitas di atas cukup besar.

\section{Kesimpulan}

Untuk meningkatkan kemampuan membaca permulaan di kelas I sekolah dasar dengan melalui Pendekatan VCT ( Value Calrifikation Teaching) dan kartu suku kata dapat berhasil. Anak merasa senang tidak dihadapkan pada satu buku pelajaran yang terdiri dari banyak tulisan sehingga menimbulkan kejenuhan. Pengembangan Pendekatan VCT ( Value Calrifikation Teaching) dan lembar kerja siswa kata lebih mudah karena bisa memanfaatkan lingkungan sebagai sumber belajar mengingat kelas $\mathrm{V}$ itu pembelajaran IPS harus bermakna dam dekat dengan lingkungan sebagai upaya memahami gejala sosial. Waktu bisa efisien karena guru tidak harus menulis di papan tulis apa yang akan diajarkan pada anak sehingga bisa efektif Bimbingan secara individual banyak peluang karena langsung sudah ada media.

Terdapat peningkatan yang sangat signifikan Penggunaan Pendekatan VCT ( Value Calrifikation Teaching) dan lembar kerja siswa terhadap kemampuan memahami nilai-nilai kedisiplinan yang dapat diteladani dari tokoh-tokoh sejarahpada masa hindu, budha dan islam.

\section{SARAN}

Mengingat keberhasilan memahami sikap kedisiplinan dari para tokoh pejuang melalui Pendekatan VCT (Value Calrifikation Teaching) dan lembar kerja siswa ini menunjukkan peningkatan yang sangat signifikan maka harapan peneliti :
“ Hendaknya para guru dapat melaksanakan pembelajaran dengan memanfaatkan Metode dan media-media yang menarik apakah dengan gambar, ataupun dengan memanfaatkan multi media dalam mata pelajaran IPS.

\section{DAFTAR PUSTAKA}

Arikunto, Suharsimi. 2010. Prosedur Penelitian : Suatu Pendekatan Praktik (Edisi Revisi). Rineka Cipta. Jakarta.

Amir Daien Indrakusuma,1973. Pengantar Ilmu Pendidikan, (Malang: Usaha Nasional,

Anonim, 2017 Kurikulum SDN Dasan Jontak, SDN Dasan Jontak

Bell-Gredler,1997, Belajar adalah Proses yang Dilakukan Manusia. UNS. Surakarta.

Bahri syaiful dan Aswan Zain,2002. Strategi Belajar Mengajar. Rineka Cipta. Jakarta.

BNSP. 2006. Peraturan Mendiknas no 22 dan 23 Tahun 2006. BNSP. Jakarta.

Conny Semiawan,2002. Pendidikan Keluarga Dalam Era Global, (Jakarta: PT Prenhallindo

.. 2007. Peraturan Menteri Pendidikan Nasional Republik Indonesia Nomor 42 Tahun 2007 Tentang Standar Proses. BNSP. Jakarta.

Darsono, Max. 2000. Belajar dan Pembelajaran. IKIP Semarang. Semarang.

Mulyana, Dedey. 2003. Metodologi Penelitian Kualitatif Paradigma Baru Ilmu Komunikasi dan Ilmu Sosial Lainnya. Remaja Rosda Karya. Bandung.

Sardjiyo,dkk,2014. Pendidikan IPS di SD, Universitas Terbuka,Banten - Indonesia

Slameto. 2003. Kamus Besar Bahasa Indonesia. Balai Pustaka. Jakarta.

Subari, 1994. Supervisi Pendidikan, (Jakarta: Bumi Aksara,

Sukarna, 1992 Dasar-Dasar Manajemen, (Bandung: Mandar Maju,

Sjikabuden, 1984, Pengantar Media Pendidikan, Malang: FIP IKIP Malang

Undang-undang Republik Indonesia Nomor 20 Tahun 2003 Tentang Sistem Pendidikan Nasional (UU Sisdiknas 2003) 
Winamo Surachmad, 1990, Pengantar

Penelitian Ilmiah, Bandung:Tarsito 